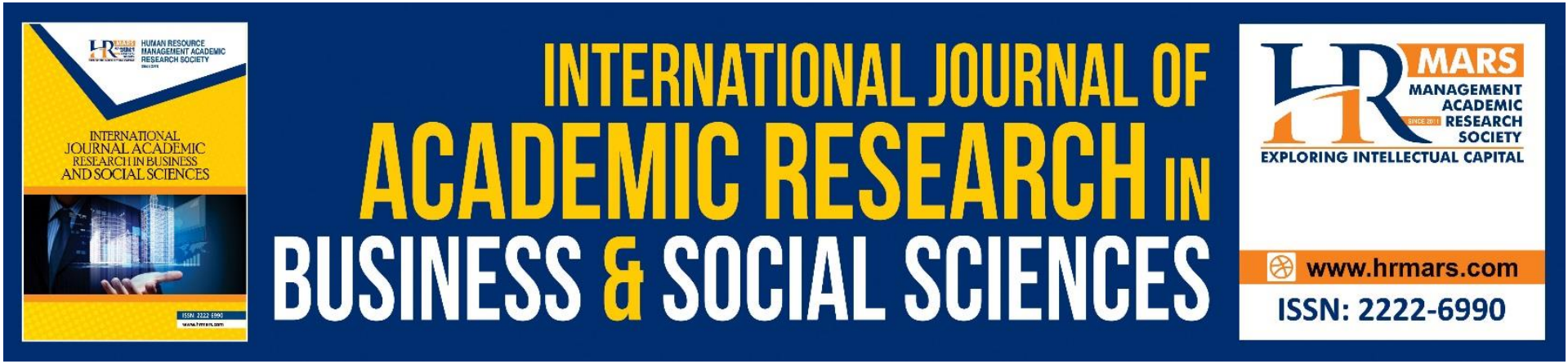

\title{
A Review on Service Quality Dimensions in Higher Education Sector and Research Prospects after COVID-19 Pandemic
}

\author{
Li Feifei, Mooi Wah Kian \& Joseph Adaikalam
}

To Link this Article: http://dx.doi.org/10.6007/IJARBSS/v12-i1/12052

DOI:10.6007/IJARBSS/v12-i1/12052

Received: 14 November 2021, Revised: 16 December 2021, Accepted: 29 December 2021

Published Online: 10 January 2022

In-Text Citation: (Feifei et al., 2022)

To Cite this Article: Feifei, L., Kian, M. W., \& Adaikalam, J. (2022). A Review on Service Quality Dimensions in Higher Education Sector and Research Prospects after COVID-19 Pandemic. International Journal of Academic Research in Business and Social Sciences, 12(1), 328-337.

Copyright: (c) 2022 The Author(s)

Published by Human Resource Management Academic Research Society (www.hrmars.com)

This article is published under the Creative Commons Attribution (CC BY 4.0) license. Anyone may reproduce, distribute, translate and create derivative works of this article (for both commercial and non0-commercial purposes), subject to full attribution to the original publication and authors. The full terms of this license may be seen at: http://creativecommons.org/licences/by/4.0/legalcode

Vol. 12, No. 1, 2022, Pg. $328-337$

Full Terms \& Conditions of access and use can be found at http://hrmars.com/index.php/pages/detail/publication-ethics 


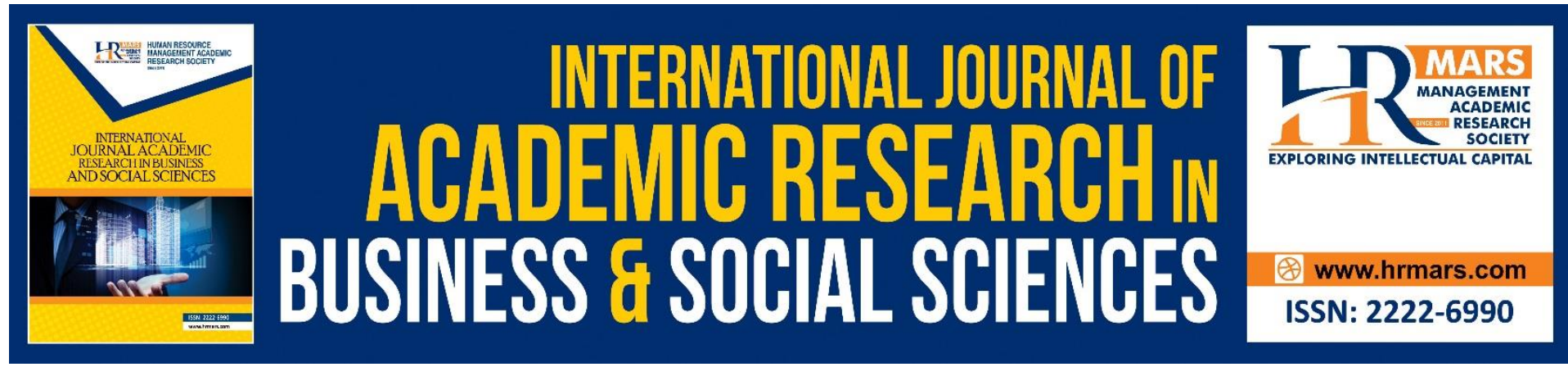

\title{
A Review on Service Quality Dimensions in Higher Education Sector and Research Prospects after COVID-19 Pandemic
}

\author{
Li Feifei ${ }^{1}$, Dr. Mooi Wah Kian² \& Joseph Adaikalam³ \\ ${ }^{1} \mathrm{PhD}$ Researcher, Binary University of Management \& Entrepreneurship, Malaysia. \\ ${ }^{2}$ Professor, Infrastructural University of Kuala Lumpur and ${ }^{3}$ Professor, Founder and \\ Executive Chairman, Binary University of Management \& Entrepreneurship, Malaysia.
}

\begin{abstract}
With the development of higher education marketization and internationalization, the importance of service quality in higher educational institutions (HEIs) has been paid more and more attention by academic circles and the industry. This article reviews the research literature on service quality in HEls, and examines several influential measurements of service quality in HEls. Based on the literature review, this article will also discuss the following issues: what effect will the e-learning model emerging in the post-COVID-19 era have on higher education services? What changes will happen to the dimensions of service quality in HEIs? This article summarizes the findings on service quality in higher education sector and provides an outlook on future research trends, contributing to further in-depth research in academia and reform and policy-making in industry.
\end{abstract}

Keywords: Service Quality, Higher Education, Covid-19, E-Learning

\section{Introduction}

In academia and industry, some people regard higher education as a kind of service (HennigThurau et al., 2001; Mazzarol, 1998; Oldfield and Baron, 2000). Since the core service of higher education is to transfer knowledge and skills to students, higher education is intangible in this process. Because the transfer of knowledge and skill depends on teachers and is influenced by teachers' individual factors, curriculum, teaching content, students, teaching time and other variables, higher education services are heterogeneous. Higher education services are also inseparable in nature as teachers provide knowledge-based services that are also enjoyed by students at the same time. Although we can use modern technology to preserve teachers' teaching contents, due to the individual differences of students and the interactive nature of higher education services, we cannot preserve all higher education services, so higher education is also perishable. Based on the above analysis, higher education services have the characteristics of intangible, heterogeneous, inseparable and perishable, which are similar to the general service trade. In the WTO's classification of world service trade, higher education service is classified into the fifth of the 12 categories.

The issue of service quality has received extensive attention from scholars and university administrators. The main reasons are as follows. The marketization and internationalization 
of higher education have put schools under intense competitive pressure. In 2000, the total number of international students in the world was about 2 million. This number had climbed to more than 5.3 million by 2017 (UNESCO, 2019). Higher education institutions (HEIs) need to face competition from global universities, as well as challenges such as funding cuts, rising tuition rates, questioned public opinions and students' attrition. As a result, service quality has become an important factor influencing student decisions. Research shows that service quality is a antecedent of students' satisfaction (Cronin and Taylor, 1992; Dabholkar et al., 2000; Zeithaml et al., 2008). Satisfied students can bring word-of-mouth action, which can greatly promote the establishment of a good reputation, raise funds, and attract students for the HEls (Khaled et al., 2019; Alvis \& Rapaso, 2007; Elliott and Shin, 2002). Therefore, the importance of service quality has been increasingly highlighted in higher education sector.

With the outbreak of Corona Virus Disease 2019 (COVID-19), new changes have taken place in the environment and conditions for the development of higher education (Hossain et al., 2020). For schools, the strict border control of in some countries has affected the size of their international student enrollment, further exacerbating the problem of reduced funding. For example, more than half of the students in Australian universities come from China and India, and a large part of their main source of income comes from international students. UCL, the third-largest research university in the UK, has $£ 300$ million, or $20.2 \%$ of its income comes from students from non-EU countries (Marginson, 2020) As a result, the COVID-19 pandemic has left schools with a huge challenge of student loss and finance constraints. For students, the explosion of COVID-19 has prevented some students from returning to campus and they have passively chosen an online learning option. This has left them with the problem of adapting to virtual learning, and new ways of university governance. Whether these new changes have an impact on the service quality of HEls deserves our attention, and needs to be further studied.

The purpose of this article is to review the research literature on higher education service quality, to explore the impact of online learning models on higher education service quality, and to provide an outlook on higher education service quality research in the post-epidemic era.

\section{Literature Review \\ What is S ervice Quality?}

Professor G. Pellicelli of the University of Turin in Italy believes that there are two most common definitions of service quality: quality meets a characteristic; quality meets or exceeds customer expectations (Pellicelli, 1999) In fact, the latter definition is widely accepted, which falls within the "customer-led" or "user-led" category. Some researchers believed that quality is a form of overall evaluation of a product, which is similar to attitude. (Olshavsky, 1985; Parasuraman et al., 1988) Service quality is a comparison from what customers expect with their perceptions of the performance of firms providing the services (Bashir et al., 2020; Sasser et al., 1978; Gronroos,1982). Therefore, perceived service quality is viewed as the degree and direction of discrepancy between consumers' perceptions and expectations (Parasuraman et al.,1988). When the perceived service quality is lower than customers' expectations, the service quality is unacceptable. When the perceived service quality is consistent with customers' expectations, the service quality is satisfactory. When the perceived service quality exceeds the customers' expectations, the service quality is ideal. 
Therefore, some scholars define service quality as " consistently meeting or exceeding customer's expectations "(Lewis, 1989; Creedon, 1988).

\section{The Composition of Service Quality}

Regarding the components of service quality, Grönroos (1984) proposed two dimensions: a technical outcome-related dimension and a functional process-related dimension.1) Technical quality is also called outcome quality, which is what the customers receive after the service process. 2) Functional quality is also called process quality, which is the way customers receive services and their experience in the process of service production and consumption. Grönroos (1984) also pointed out that corporate image affected the customer's evaluation of service quality, and both technical quality and functional quality will have an important impact on the company's image.

In addition, some scholars have proposed that the physical environment of the service encounter is also a dimension of service quality (Lehtinen and Lehtinen,1991; Rust and Oliver,1994; Brady and Cronin, 2001). Physical environment is composed of physical resources, technologies and other physical elements during the service process. Bitner (1992) referred to physical environmental factors as services cape, and Lehtinen (1991) believed that the physical environment is part of the physical quality. However, Grönroos (2016) pointed out that the physical environment is also part of the functional quality.

Polas et al (2020); Holmlund (1997) also proposed economic consequence as a dimension of service quality. The economic consequences are directly seen as the price of goods or services, and indirectly seen as the economic sacrifices made by customers caused by a certain solution.

\section{The Dimensions of Service Quality}

In 1985, PZB team proposed a service quality gap analysis model which is referred to as the SERVQUAL model. (Parasuraman et al., 1985) They identified 5 dimensions as the most important factors for customers to perceive service quality. The 5 dimensions are tangibles, reliability, responsiveness, assurance and empathy. Stodnick and Rogers' research showed that in a specific classroom setting, SERVQAUL scale was reliable and valid. But some research reported that they could not replicate the five-factor structure of SERVQAUL scale. (Cuthbert, 1996; O'Neill, 2003; Sahney et al., 2004). Therefore, the application of the SERVQAUL scale to higher education has been questioned by some scholars. Some researchers hold the view that students do not form clear expectations of higher education services (Joseph and Joseph, 1997).

Cronin and Taylor (1992) proposed a performance-only scale which is called SERVPERF model. SERVPERF adopts the same dimensions with SERVQUAL, but they only measure consumers' perception of performance. Some studies apply the SERVPERF scale to the field of higher education, which proves that the SERVPERF scale is more applicable (Oldfield and Baron, 2000; Abdullah, 2006). Abdullah (2006) proposed Higher Education Performance-only model which is also known as HEdPERF. He used 6 dimensions to measure the service quality of higher education: non-academic aspects, academic aspects, reputation, access, programme issues and understanding.

Teeroovengadum et al (2016) put forward a Higher Education Service Quality model (HESQUAL). The model contains 5 dimensions to measure service quality: administrative 
quality; physical environment quality; core educational quality; support facilities quality and transformative quality. Annamdevula \& Bellamkonda (2012) developed a new instrument called HiEdQUAL to measure service quality in higher education sector. They explored five dimensions of service quality: teaching and course content, administrative services, academic facilities, campus infrastructure and support services of service quality within the higher education sector.

Leblanc and Nguyen (1997) identified 7 dimensions of service quality in HEls: contact personnel; reputation; physical evidence; administration; curriculum; responsiveness; and access to facilities. Lagrosen et al (2004) identified 11 dimensions of service quality in $\mathrm{HEl}$ : corporate collaboration; information and responsiveness; courses offered; campus facilities; teaching practices; internal evaluations; external evaluations; computer facilities; collaboration and comparisons; post-study factors; and library resources. Sultan and Wong (2010) developed a performance-based service quality model which included 8 dimensions of service quality: dependability, effectiveness, capability, efficiency, competencies, assurance, unusual situation management, and semester-syllabus.

In a word, the current research on the measurement of higher education service quality has achieved fruitful results, but the existing research results still have some problems in practical application and have been criticized. The biggest problem is that with the COVID-19 pandemic, many HEls have to use online teaching mode. Some students have not even entered the campus to study and live, which will inevitably affect the students' learning experience and change their perception of the HEls.

\section{E-service Quality}

With the development of network technology, e-commerce and e-service show a trend of rapid development, so some research began to study e-service quality. The research is mainly based on the research of service quality, combined with the characteristics of e-service, to study the measurement scale of e-service quality. Loiacono, Watson, and Dale (2002) proposed WebQual, which consisted of 12 dimensions to measure web site quality: trust, response time, intuitive operations, emotional appeal, ease of understanding, relative advantage, information fit-to-task, innovativeness, tailored communications, visual appeal, consistent image, and inline completeness. However, this model is based on the Theory of Reasoned Action and the Technology Acceptance Model which is too complicated to measure. Yoo and Donthu (2001) put forward a "SITEQUAL" model to evaluate an Internet shopping site. SITEQUAL consisted of four dimensions - online system quality, product service quality, and customer service quality. Wolfinbarger and Gilly (2003) developed e-TailQ scale, including four factors - website design, fulfillment/reliability, privacy/security and customer service- to evaluate online retail quality. Parasuraman, Zeithaml, and Malhotra (2005) advanced a multiple-item scale (E-S-Scale) for measuring E-service quality which consisted of the basic E-S-QAUL scale and E-RecS-QAUL scale. The basic E-S-QAUL scale is a 22-item scale of four dimensions: efficiency, fulfillment, system availability, and privacy. E-RecS-QAUL scale is only important to customers who have unconventional contact with the website. It includes 11 items in three dimensions: responsiveness, compensation and contact. In a word, both eservice and e-learning service provide services through the network. As a medium of delivering service quality, the network affects the perception of service quality (Al Qalhati et al., 2020). Therefore, the measurement of e-service can be used as a reference for the 
measurement of e-learning service. However, due to the intangible, long-term and bidirectional characteristics of learning service, the measurement of e-learning service quality has its unique dimension.

\section{E-learning Service Quality}

The main difference between e-learning and traditional classroom learning is that e-learning is limited by distance, so the interaction frequency and efficiency between teachers and students, students and students are lower, which brings challenges to the improvement of elearning service quality. Javed et al. (2020), Shaik et al. (2006) and Martinez-Arguelles et al. (2013) believed that instructional service quality (teaching service or core service) and noninstructional service quality (facilitative or administrative services, support services and user interface) constitute two dimensions of e-learning service quality. Lin (2007) and Wang et al. (2007) believed that the three dimensions of system quality, information quality and service quality can be used to measure e-learning service quality. Ozkan and Koseler (2009) developed a e-learning assessment model consisted of six dimensions - supportive issues, instructor attitudes, learner perspective, content quality, service quality, and system quality. Al-Samarraie et al (2017) identified five factors - information quality, task-technology fit, system quality, utility value, and usefulness - to measure e-learning service quality. Al Qalhati et al (2020); Peltier et al (2007); Goh et al (2017) holt the view that course content /course design, interactions between students and students, interactions between instructors and students are determinants to evaluate students perceived service quality in online learning setting environment. Peltier et al (2007) believed that course content is the most important factor. They also found that lecture delivery quality, course structure, and instructor support and mentoring are dimensions of e-learning service quality. Uppal et al (2018); Agarwal et al (2021) used some factors in the SERVQAUL scale to measure the quality of e-learning services, and add some factors related to e-learning. They identified the following factors: empathy, responsiveness, reliability, assurance, tangibility, website content and privacy and learning content. To sum up, we can identify several important factors to form an e-learning service quality measurement scale. Factors mentioned several times by scholars can be considered important, for example, course content, utility value, instructor attitudes, interaction between students and students, interactions between instructors and students, empathy, responsiveness, reliability, assurance, tangibility, security/privacy, and ease of use. These factors can be divided into the following three groups: instructional service quality, information system quality and support service quality.

\section{Discussion and Implication}

Reviewing the existing literature research, we can find that the research development from service quality to higher education service quality is the application of the concept of service quality from general to specific. The research development from e-service quality to elearning service quality is the continuous development of the concept of service quality that keeps pace with the times. As our understanding of the concept of service quality continues to deepen, the measurement of e-learning service quality should include the factors of service quality in traditional classroom learning and the factors in the service delivery process brought by e-learning. We can use SERVQAUL, SERVPERF, HEdPERF and other widely accepted scales to measure the service quality of traditional classroom learning, plus the factor of course content that is considered to have a significant effect. For the factors in the service delivery process brought by e-learning, we can combine the characteristics of e-learning and 
take system quality, consisting of security/privacy, ease of use and interactive effectiveness, as measurement factors.

We can also classify the service quality of traditional classroom learning as technical quality and the service quality in the delivery process of e-learning as functional quality. We find that the physical environment can also be considered as a factor, which is rarely mentioned in the current research on e-learning service quality, and it deserves our attention in the future. In future research, we can further promote the study of the relationship between e-learning services quality and students' e-learning satisfaction and loyalty, adding factors such as HEIs' reputation and student cultural differences to the model, to bring more meaning insights.

The original value of this article is to sort out the research literature on service quality, and complete the preliminary construction of the e-learning service quality measurement framework based on the literature review. Based on this, we can look forward to the future research landscape and provide reference value for related researchers and practitioners to improve the quality of e-learning services in the post-epidemic era.

\section{Limitation and Future Research}

Although this article provides original value for research in this field, this research still has certain limitations. The biggest limitation is that this article fails to provide a complete set of factors to evaluate e-learning service quality. Secondly, due to the limited length of the article, this article fails to introduce the factors involved in the existing research in detail. Therefore, the e-learning service quality measurement framework proposed in this article is only a preliminary framework, and it has not been refined into a complete and detailed framework. Finally, the e-learning service quality measurement framework proposed in this article is only at the theoretical construction level, and has not yet been implemented into the empirical research stage. Its credibility and validity need to be further verified. This is also the direction of future research and the author's next work plan.

\section{References}

Abdullah, F. (2006).The development of HEdPERF: a new measuring instrument of service quality for the higher education sector. International Journal of Consumer Studies, 30(6), 569-581.

Al Qalhati, N., Karim, A. M., Al Mughairi, B., Al Hilali, K., \& Hossain, M. I. (2020). Study on Job Satisfaction among Teachers in Sultanate of Oman. International Journal of Academic Research in Business and Social Sciences. 10(10), 422-434.

Al Qalhati, N., Karim, A. M., Al Mughairi, B., Al Hilali, K., \& Hossain, M. I. (2020). Technology and HR Practices in Educational Sector in Sharqiya Governate of Oman. International Journal of Academic Research in Business and Social Sciences. 10(10), 435-443.

Al-Samarraie, H., Teng, K. B., Alzahrani, I. A., \& Alalwan, N. (2017). E-learning continuance satisfaction in higher education: A unified perspective from instructors. Studies in Higher Education, 8(March), 1-17.

Alvis, H., Rapaso, M. (2007). Conceptual model of Student Satisfaction in Higher Education. Total Quality Management \& Business Excellence, 18(5), 571-588.

Bashir, M. A., Ali, M. H., Wai, L. M., Hossain, M. I., \& Rahaman, M. S. (2020). Mediating Effect of Customer Perceived Value on the Relationship between Service Quality and Customer Satisfaction of E-Banking in Bangladesh. International Journal of Advanced Science and Technology. Vol. 29, No. 2, pp. $3590-3606$ 
Bitner, M. J. (1992). Servicescapes: the impact of physical surroundings on customers and employees. Journal of Marketing, 56, 57-71.

Brady, M. K., and Cronin J. J., Jr. (2001).Some New Thoughts on Conceptualizing Perceived Service Quality: A Hierarchical Approach. Journal of Marketing, 65, 34-49.

Grönroos, C. (2016). Service Management and Marketing: Managing the Service Profit Logic (4th edition), Hershey, PA : John Wiley \& Sons, Inc.

Creedon, J. (1988). Inside Met Life's Growth Strategy. Journal of Business Strategy, 9(1),2327.

Cronin, J. J. J., Taylor, S. A. (1992). Measuring service quality: A reexamination and extension. Journal of Marketing, 56(3), 55-68.

Cuthbert, P. F. (1996). Managing service quality in HE : is SERVQUAL the answer ? Part 2, Managing Service Quality, 6(3), 31-35.

Dabholkar, P. A., Shepherd, C. D., Thorpe, D. I. (2000). A comprehensive framework for service quality: an investigation of critical conceptual and measurement issues through a longitudinal study, Journal of Retailing, 76( 2), 139-173.

General Agreement on Trade in Services (2021). Retrieved from the website of World Trade Organization, https://www.wto.org/english/docs_e/legal_e/26gats_01_e.htm\#articleXIII.

Goh, F. C., Leong, M. C., Kasmin, K., Hii, K. P., \& Tan, K. O. (2017). Students' experiences, learning outcomes and satisfaction in e-learning. Journal of E-learning and Knowledge Society, 13(2), 117-128.

Grönroos, C. (1984). A service quality model and its marketing implications. European Journal of Marketing, 18 (4),36-44.

Gronroos, Christian. (1982). Strategic Management and Marketing in the Service Sector, Helsingfors: Swedish School of Economics and Business Administration.

Hennig-Thurau, T., Langer, M. F., Hansen, U. (2001).Modeling and managing student loyalty: an approach based on the concept of relationship quality, Journal of Service Research, 3 (4), 331-344.

Holmlund, M. (1997). Perceived Quality in Business Relationships. Helsinki/Helsingfors, Finland: Swedish School of Economics and Business Administration.

Hossain, M. I., Polas, M. R. H., Rahman, M. M., Islam, T., \& Jamadar, Y. (2020). An Exploration of COVID-19 Pandemic and its Consequences on FMCG Industry in Bangladesh. Journal of Management Info, 7(3), 145-155. https://doi.org/10.31580/jmi.v7i3.1484

Javed, M., Hock, O. Y., \& Asif, M. K., Hossain, M. I. (2020). Assessing the Impact of Emotional Intelligence on Job Satisfaction among Private School Teachers of Hyderabad, India. International Journal of Psychosocial Rehabilitation. 24(4). 5035-5045

Joseph, M., and Joseph, B. (1997). Service quality in education: a student perspective. Quality Assurance in Education, 5 (1), 15-21.

Khaled, A. S., Ahmed, S., Tabash, M. I., Al-Homaidi, E. A., \& Hossain, M. I.(2019). The Impact of Technological and Marketing Innovations on Retailing Industry: Evidence of India. Journal of Reviews on Global Economics, 8, 948-957

Lagrosen, S., Seyyed-Hashemi, R., \& Leitner, M. (2004). Examination of the dimensions of quality in higher education. Quality Assurance in Education,12 (2), 61-69.

LeBlanc, G., and Nguyen, N. (1997). Searching for excellence in business education: an Lewis, B. R. (1989).Quality in the Service Sector - A Review. International Journal of Bank Marketing, 7(5), 4-12. 
Lin, F. H. (2007). Measuring online learning systems success: Applying the updated DeLone and McLean model. Cyber psychology \& Behavior, 10(6), 817-820.

Loiacono, E., Watson, R., \& Dale, G. (2002). WebQual: A Measure of Web Quality. American Marketing Association,13,432-438.

Marginson, S. (2020). The world is changing: Higher education and the COVID-19 pandemic. Paper presented at the Global Higher Education Webinar Series, 29 September 2020, Lingnan University.

Martinez-Arguelles, J. M., Callejo, B. M., \& Farrero, M. C. J. (2013). Dimensions of perceived service quality in higher education virtual learning environments. Universities and Knowledge Society Journal, 10(1), 268-285.

Mazzarol, T. (1998). Critical success factors for international education marketing. International Journal of Educational Management, 12(4), 163-175.

O'Neill, M. A. (2003). The influence of time on student perceptions of service quality: the need for longitudinal measures. Journal of Educational Administration,41 (3), 310-324.

Oldfield, B. M., Baron, S. (2000). Student perceptions of service quality in a UK university business and management faculty. Quality Assurance in Education, 8(2), 85-95.

Olshavsky, R. W. (1985). Perceived Quality in Consumer Decision Making: An Integrated Theoretical Perspective, in Perceived Quality, J, Jacoby and J, Olson (eds,),

Ozkan, S., \& Koseler, R. (2009). Multi-dimensional students' evaluation of e-learning systems in the higher education context: An empirical investigation. Computers \& Education, 53, 1285-1296.

Parasuraman, A., Valarie, A., Zeithaml, Leonard, L. B. (1985). A Conceptual Model of Service Quality and Its Implications for Future Research. The Journal of Marketing, 49(4), 41-50.

Parasuraman, A., Zeithaml, V. A., \& Malhotra, A. (2005). E-S-Qual: A multiple-item scale for assessing electronic service quality. Journal of Service Research, 7(3), 213-233.

Peltier, W. J., Schibrowsky, A. J., \& Drago, W. (2007). The interdependence of the factors influencing the perceived quality of the online learning experience: A causal model. Journal of Marketing Education, 29(2), 140-153.

Polas, M. R. H., Juman, M. K., Karim, A. M., Tabash, M. I., Hossain, M. I. (2020). Do Service Quality Dimensions Increase the Customer Brand Relationship among Gen Z? The Mediation Role of Customer Perception between the Service Quality Dimensions (SERVQUAL) and Brand Satisfaction. International Journal of Advanced Science and Technology. 29( 4), 1050-1070

Rust, R. T., and Oliver, R. L. (1994). Service Quality Insights and Managerial Implications from the Frontier. In Service Quality: New Directions in Theory and Practice. Ed. R. T. Rust and R. L. Oliver. Thousand Oaks, CA: Sage.

Annamdevula, S., \& Bellamkonda, R. S. (2012). Development of HiEdQUAL for Measuring Service Quality in Indian Higher Education Sector. International Journal of Innovation, Management and Technology,3(4),412-416.

Sahney, S., Banwet, D., and Karunes, S. (2004). A SERVQUAL and QFD approach to total quality education. International Journal of Productivity and Performance Management, 53, 143-166.

Sasser, W. Earl, Jr., R. Paul Olsen, and Wyckoff, D. D. (1978). Management of Service Operations: Text and Cases, Boston: Allyn \& Bacon.

Shaik, N., Lowe, S., \& Pinegar, K. (2006). DL-sQUAL: A multiple-item scale for measuring service quality of online distance learning programs. Online Journal of Distance Learning Administration, 9(2), 201-214. 
Sultan, P., and Wong, H. (2010).Performance-based service quality model: an empirical study on Japanese universities. Quality Assurance in Education, 18(2), 126-143.

UNESCO Institute for Statistics (UIS). (2021). Retrieved from the website of UIS, http://data.uis.unesco.org/Index.aspx?queryid=172.

Uolevi Lehtinen \& Jarmo, R. L. (1991). Two Approaches to Service Quality Dimensions, The Service Industries Journal , 11(3),287-303.

Wang, S. Y., Wang, Y. H., \& Shee, Y. D. (2007). Measuring e-learning systems success in an organizational context: Scale development and validation. Computers in Human Behavior, 23, 1792-1808.

Wolfinbarger, M. F., \& Gilly, M. C. (2003). ETailQ: Dimensionalization, measuring and predicting Etail quality. Journal of Retailing,79(3), 183-198.

Yoo, B., \& Donthu, N. (2001). Developing a scale to measure the perceived quality of an internet shopping site (Sitequal). Quarterly Journal of Electronic Commerce, 2(1), 3146.

Zeithaml, V. A., Bitner, M. J., Gremler, D. D. (2008). Services Marketing-Integrating Customer Focus Across the Firm, Boston: McGraw Hill. 